Revue Française de Civilisation Britannique

\title{
Review article: The Politics of Remembering the Suffragettes
}

Politique de la mémoire: le cas des suffragettes

\section{Laura Schwartz}

\section{(2) OpenEdition}

\section{Journals}

Electronic version

URL: http://journals.openedition.org/rfcb/1841

DOI: $10.4000 /$ rfcb. 1841

ISSN: 2429-4373

\section{Publisher}

CRECIB - Centre de recherche et d'études en civilisation britannique

\section{Electronic reference}

Laura Schwartz, "Review article: The Politics of Remembering the Suffragettes », Revue Française de Civilisation Britannique [Online], XXIII-1 | 2018, Online since 20 March 2018, connection on 22 Auqust 2020. URL : http://journals.openedition.org/rfcb/1841; DOI : https://doi.org/10.4000/rfcb.1841

This text was automatically generated on 22 August 2020

\section{cc) (1)}

Revue française de civilisation britannique est mis à disposition selon les termes de la licence Creative Commons Attribution - Pas d'Utilisation Commerciale - Pas de Modification 4.0 International. 


\title{
Review article: The Politics of Remembering the Suffragettes
}

\author{
Politique de la mémoire : le cas des suffragettes
}

\author{
Laura Schwartz
}

1 The 2015 film Suffragette grossed 4.7 million at the box office, was screened in cinemas across the UK and was awarded "Best Movie about Women" by the Women Film Critics Circle Awards. ${ }^{1}$ Finally the subject of my own historical research had hit the mainstream, generating much debate not just among historians but also within activist circles and on social media. Yet not all the attention was positive, especially with regards to the race politics of both the film and the movement whose story it told. This posed some difficult questions for me as a historian and as a feminist committed to organising for radical social change. How should I best engage with the explicit politicisation of my academic research, and how could I use history to inspire presentday struggles without romanticising, demonising or oversimplifying the past?

Directed by Sarah Gavon and written by Abi Morgan, Suffragette sets out to tell the story of the "foot soldiers" of the militant suffrage movement, rejecting a focus on the famous Pankhurst family to look instead at the working-class women active in the Women's Social and Political Union (WSPU). This was a refreshing take on a movement that is often represented, at least on screen and in the school room, as a story of posh and slightly unhinged ladies in impressive hats, to whom we all have to feel extremely grateful. The WSPU did indeed recruit among the wealthy, and was led mainly by middle-class women. Yet, as feminist historians have been arguing for decades, it also gained significant support from women workers - many of whom joined the fight, despite the difficulties of combining this with jobs in factories or domestic service and their responsibilities as wives and mothers. ${ }^{2}$

While Suffragette was widely congratulated for its attention to working-class militants, ${ }^{3}$ the most substantive and widely discussed critique was of its race politics. Kirsten West Savali and Sarah Kwei criticised the film not only for failing to cast actors of colour and represent suffragettes of different ethnicities, but also for its publicity photoshoot in Time Out magazine that used a line from an Emmeline Pankhurst speech in which she 
declared "I'd rather be a rebel than a slave". They argued that the filmmakers had failed to consider the slogan's racist origins and contemporary resonances: the connotations of the term 'rebel' with the pro-slavery South in the US Civil War, and the opportunistic comparison that Emmeline Pankhurst made on a visit to the United States in 1913 when she called upon her audience to free women just as they had already freed "the Negro", while ignoring the continued oppression of African Americans. ${ }^{4}$ Many discussions on feminist social media extended this critique not only to the film's representation of this historical period, but to the suffrage movement itself, which was condemned by some as nothing more than white feminism for white feminists. ${ }^{5}$

4 The creators of Suffragette had taken great care to offer a historically accurate portrayal of the militant suffrage movement, consulting Professor June Purvis and appointing Professor Krista Cowman as the historical advisor. Sarah Gavron even published an article on the making of the film in the leading academic journal Women's History Review. ${ }^{6}$ The importance of historical accuracy was also foregrounded in the response to criticisms of Suffragette's race politics. Time Out's official reply to complaints about its photoshoot insisted that Emmeline Pankhurst's use of the term "rebel" had been taken out of context and had nothing to do with the US Civil War. ${ }^{7}$ When interviewed on BBC Radio, Sarah Gavron, reminded her critics that the British suffrage movement should not be confused with its counterpart in the United States. Whereas, she argued, North American suffrage had at times excluded Black women from its ranks, this did not occur in Britain. Gavron also maintained that it was anachronistic to demand that women of colour be represented in the film, since in 1912 there were very few Black people living in the UK. Researchers for the film had only found one woman of colour involved in the WSPU, the Indian Princess Sophia Duleep Singh, who was not part of the working-class women's movement that the film focused on. ${ }^{8}$

Historian Sumita Mukherjee wrote about the mis-use of a 1911 photograph of 'Indian suffragettes', widely circulated on social media by those who condemned their erasure from the film. Although she argued for the need to move away from Anglo-centric narratives of the suffrage movement, and to recognise the degree to which it was a global struggle fought for by women around the world, Mukherjee was nevertheless troubled by the uncritical deployment of the photograph. As she pointed out, the Indian women in the picture were not, in fact, fighting for votes for Indian women living under colonial rule, but were participating in a British suffrage procession that celebrated Empire. Mukherjee argued that by ignoring the specificity of these women's backgrounds and politics (Sophia Duleep Singh was well connected within the British establishment and occupied a grace and favour apartment at the Royal Palace of Hampton Court), even the most well-intentioned moves to celebrate "diversity" within the British suffrage movement risked obscuring important political differences between these elite Indian women in Britain and the anti-imperialist women's movement in India and Pakistan. ${ }^{9}$

6 In the case of Time Out and Gavron's responses, however, I was concerned that invoking "facts" and historical "expertise" was a way to avoid a debate about a wider truth namely the problematic relationship that much feminism past and present has had with race and racism. Emmeline Pankhurst may not, in her "I'd rather be a rebel than a slave" speech, have been supporting the pro-slavery South, but she and her daughter Christabel did, during and after World War I, promote a right wing and anti-migrant form of patriotism, and were part of a feminist movement that often supported the 
British Empire. ${ }^{10}$ How could I, as an activist greatly inspired by the politically rich, diverse and often revolutionary movement that I research, convey this to a wider audience without ignoring its problems or its complexity? And how could I, as a (white) historian, listen to and learn political lessons from the concerns of many of today's feminist activists (including many Black feminists) who felt alienated from the feminist history canon, without renouncing much that is valuable and important about that history?

One strategy was to delve more deeply into the history itself, in a piece I published on the website of the London-based activist collective Feminist Fightback that I helped to found 10 years ago. ${ }^{11}$ Here I attempted to respond to the North American emphasis within many of the criticisms of Suffragette by exploring questions of race and racism in the British context more specifically. I wrote of how the women's suffrage movement in the United States made a conscious decision to renounce the struggle against slavery and the emancipation of African Americans (in their early years the two movements had been closely intertwined), in the hope that this would make their demands for rights for white women more palatable to the powers that be. The British suffrage movement, however, never experienced such an explicit moment of betrayal and rupture. In contrast to the United States, the primary site in which the racism of the British state and society in the nineteenth and early twentieth century played out was not the metropole, but its Empire. Britain was home to some people of colour in this period, but they were a small fraction of the metropolitan population and their history is not, therefore, directly comparable to that of people of colour in North America. ${ }^{12}$ Britain carried out exploitation, segregation, violence against and genocide of people of colour "somewhere else" - in the territories it colonised in the Indian subcontinent and parts of Africa. The only sizeable wave of colonial migration into Britain at this time was from Ireland, whose population was both "white" and highly racialized. ${ }^{13}$

This had significant implications for how the race politics of British feminism played out, meaning that the movement followed a somewhat different path from what occurred in the United States. Historians Antoinette Burton and Claire Midgley, among others, have written about the dominance of imperialist ideas in the British women's movement. White women frequently argued for political rights for themselves, on the grounds that this would better enable them to play their part in Empire and/or "rescue" their "sisters" in the colonised territories from oppression at the hands of more "backward" societies. ${ }^{14} \mathrm{~A}$ destructive legacy that has weighed heavy on British feminism, and continues to shape the present-day political landscape. Yet there was also space in Britain for currents of anti-imperialist and anti-racist feminism to develop - exemplified by women such as Annie Besant, Harriet Law and Catherine Impey, who were also supporters of women's suffrage. ${ }^{15}$ This alternative tradition of feminist politics was certainly a minority one, but it does complicate any attempts to dismiss the history of this movement as "white feminism" concerned solely with the rights of white women and excluding people of colour. The women's suffrage movement in Britain in the early decades of the twentieth century was exceptionally politically diverse, involving conservatives, liberals, socialists, Catholics, Protestants, Jews, Theosophists and atheists, as well as imperialists and anti-imperialists - who frequently disagreed with and debated each other over the best way to win the vote and what they would do with it once they had it. Even members of the Pankhurst family took politically divergent paths. Rejecting the increasing conservatism and patriotism of her mother and sister, Sylvia Pankhurst pursued a socialist feminist course, organising with 
working-class women in London's East End, and was also an active and outspoken opponent of racism, imperialism and fascism throughout the whole of her life. ${ }^{16}$

None of this, of course, is news to historians. Yet the lack of historical context to many of the wider debates about the film suggests that we need to try harder at democratising our research. My intention in the Feminist Fightback blog was not to say that British feminism was any less racist than North American feminism, nor to try to absolve ourselves from the overriding legacies of a women's movement that has frequently been dominated by the needs of white middle-class women. Rather, I aimed to show how, by looking more closely at the politics of feminism and race in a historically and geographically specific context - one structured primarily by Empire and a predominantly white metropole - we see how understanding the history of racism within the women's movement solely in terms of "inclusion" vs "exclusion" is inadequate unless we also examine the political content of different strands of suffrage activism. Which, in turn, allowed me to pose some more directly political questions. Which traditions from the past might we want to draw from in feminism today, and which traditions should we reject? What were the possibilities at the turn of the twentieth century for developing an anti-racist feminism within the shadow of Empire and among a predominantly white British population? To what degree did overarching imperialist and racist discourses limit the thinking even of those white feminists who professed solidarity with their colonised "sisters"? And how do these discourses continue to structure feminist thinking today?

These discussions continued when I spoke on a panel following a packed out screening of Suffragette at the Genesis cinema in East London. The cinema's location on the Mile End Road, a stone's throw away from many of the key sites of suffrage militancy portrayed in the film, brought the past and the present together in a particularly intimate way. The audience proved perfectly capable of enthusiastically engaging with the film's powerful representations of women in struggle (heckling the police and loudly cheering the heroines), while also contributing to a thoughtful and sophisticated discussion of some of Suffragette's flaws. The risk of a film like Suffragette is not that it might "get things wrong", either historically or politically, since, at least in my experience, collective discussion of its strengths and weaknesses proved that it was possible to be both inspired by the successes of the suffrage movement and learn from its failures. Rather the most dangerous thing that we can do when we represent radical history is turn it into a museum piece, to relegate struggles for social justice to the past and imply that either there is nothing left to fight for or that social change is no longer possible. Sisters Uncut had resisted this narrative when they staged a protest against the Conservative government's cuts to domestic violence services at Suffragette's London premiere; while Feminist Fightback, who organised the Genesis screening, used the proceeds to pay for coaches to ongoing demonstrations outside Yarls Wood detention centre where, in 2018, the British state still imprisons (in this case migrant) women and where those women still use the hunger strike as a tool of resistance. I continue to hope, therefore, that knowing our history can and must help us make better use of it in the present.

11 Laura Schwartz is Associate Professor of Modern British History at the University of Warwick. She has published widely on the history of British feminism and is currently completing her third monograph Feminism and the Servant Problem: Class Conflict and Domestic Labour in the British Women's Suffrage Movement. 


\section{BIBLIOGRAPHY}

Ahmed, Rehana \& Mukherjee, Sumita (eds.), South Asian Resistances in Britain 1858-1947 (London, Continuum, 2012).

Anand, Anita, Sophia: Princess, Suffragette, Revolutionary (London, Bloomsbury, 2015)

Atkinson, Diane \& Cowman, Krista, 'Suffragette: 100 Years on Women's Rights Still Prompt Shrill Hysteria', The Telegraph 30 October 2015 http://www.telegraph.co.uk/women/womens-politics/ 11965153/Suffragette-100-years-on-womens-rights-still-prompt-shrill-hysteria.html [accessed 26 July 2017].

Bressey, Caroline, Empire, Race and the Politics of Anti-Caste (London: Bloomsbury, 2013).

Bressey, Caroline, 'Looking for Work: The Black Presence in Britain 1860-1920' Immigrants and Minorities 2 \& 3 (2010), pp. 164-182.

Bressey, Caroline, 'Racism, Anti-Racism and the Place of Blackness in the Making and Remaking of the English Working Class', Historical Reflections 41:1 (2015), pp. 70-82

Burton, Antoinette, Burdens of History. British Feminists, Indian Women, and Imperial Culture, 1865-1915 (Chapel Hill, North Carolina University Press, 1994).

Connelly, Katherine, Sylvia Pankhurst: Suffragette, Socialist and Scourge of Empire (London, Verso, 2013).

Conversation (The), 'Suffragette Busts Some Myths But Has Major Holes in Its History', 9 October 2015 https://theconversation.com/suffragette-busts-some-myths-but-has-major-holes-in-itshistory-47325 [accessed 26 July 2017]

Cowman, Krista, '"Incipient Toryism" the Women's Social and Political Union and the Independent Labour Party, 1903-1914', History Workshop Journal, /53 (Spring 2002), pp. 128-48.

Cowman, Krista, Women of the Right Spirit: Paid Organisers of the Women's Social and Political Union, 1904-1918 (Manchester, Manchester University Press, 2007).

Davis, Mary, Sylvia Pankhurst: A Life in Radical Politics (London, Pluto Press, 1999).

Delap, Lucy and Gottlieb, Julie, 'Suffragette: the Forrest Gump of Feminism' History Matters 3 November 2015 http://www.historymatters.group.shef.ac.uk/suffragette-forrest-gumpfeminism/[accessed 26 July 2017].

Gavron, Sarah, interview with Francine Stock for BBC Radio 4's The Film Programme, broadcast 11 February 2016 [accessed 15 May 2017 BBC radio player].

Gavron, Sarah, 'The Making of the Feature Film Suffragette', Women's History Review 24:6

(2015), 985-995.

Gullace, Nicoletta, 'Christabel Pankhurst and the Smethwick Election: Right Wing Feminism, the Great War and the Ideology of Consumption', Women's History Review 23:3 (2014), pp. 313-346.

Holton, Sandra Stanley, 'Silk Dresses and Lavender Kid Gloves: The Wayward Career of Jessie Craigen, Working Suffragist', Women's History Review, 5/1 (1996), pp. 129-50.

Jackson, Sarah, 'The Suffragettes Weren't Just White Middle-Class Women Throwing Stones' Guardian 12 October 2015 https://www.theguardian.com/commentisfree/2015/oct/12/ suffragettes-white-middle-class-women-pankhursts [accessed 26 July 2017]. 
John, Angela V., 'Radical Reflections? Elizabeth Robins: The Making of Suffragette History and the Representation of Working-Class Women', in Owen Ashton, Robert Fyson, and

Stephen Roberts (eds.), The Duty of Discontent: Essays for Dorothy Thompson (London, Mansell Publishing Ltd, 1995a), pp. 191-21.

Kwei, Sarah, 'Why I Protested with Sisters Uncut at the Suffragette Premier', Independent 8 October 2015 http://www.independent.co.uk/voices/why-i-protested-with-sisters-uncut-at-thepremiere-of-suffragette-a6685686.html [accessed 19 May 2017].

Liddington, Jill and Norris, Jill, One Hand Tied Behind Us: The Rise of the Women's Suffrage Movement (London, Virago, 1984).

McCarthy, Helen, 'Suffragette' 15 October 2015 Past Notes http://pastnotes.blogspot.co.uk/ [accessed 26 July 2017].

Midgley, Claire, Feminism and Empire. Women Activists in Imperial Britain, 1790-1865 (London \& New York, Routledge, 2007).

Mukherjee, Sumita, Indian Suffragettes: Networks, Trans-Nationalism and International Feminism (forthcoming).

Mukherjee, Sumita, 'That Indian Suffragettes Photo', http://sumitamukherjee.wordpress.com/ 2017/02/20/that-indian-suffragettes-photo/[accessed 15 May 2017].

Myall, Michelle, “'No Surrender!”: The Militancy of Mary Leigh, a Working-Class Suffragette', in Maroula Joannou and June Purvis (eds.), The Women's Suffrage Movement: New Feminist Perspectives (Manchester, Manchester University Press, 1998).

Purvis June, 'Suffragette: A Reply to Its Critics' 11 November 2015 http:// www.historymatters.group.shef.ac.uk/suffragette-reply-critics/ [accessed 26 July 2017].

Purvis, June, 'The Prison Experiences of the Suffragettes in Edwardian Britain', Women's History Review, 4/1 (1995), pp. 103-33.

Ramdin, Ron, The Making of the Black Working-Class in Britain (Aldershot, Gower Publishing Co., 1987).

Romero, Patricia W., E. Sylvia Pankhurst: Portrait of a Radical (New Haven \& London, Yale University Press, 1987).

Sanghani, Radhika, 'The Uncomfortable Truth about Racism and the Suffragettes' http:// www.telegraph.co.uk/women/womens-life/11914757/Racism-and-the-suffragettes-theuncomfortable-truth.html [accessed 19 May 2017].

Schwartz, Laura, Infidel Feminism: Secularism, Religion and Women's Emancipation, England 1830-1914 (Manchester, Manchester University Press, 2013).

Schwartz, Laura, 'Knowing Our History Helps Us to Make Better Use of It in the Present', Feminist Fightback, 13 October 2015 http://www.feministfightback.org.uk/some-thoughts-on-kirstenwest-savalis-article-sister-suffragette/.

Schwartz, Laura, 'Film Review: Suffragette Explores the Lives of Working-Class Women' History Today 8 October 2015 http://www.historytoday.com/laura-schwartz/film-review-suffragette Time Out, http://www.timeout.com/london/film/statement-response-t-shirt-complaints [accessed June 2016].

Visram, Rozina, ' Duleep Singh, Princess Sophia Alexandra (1876-1948)', Oxford Dictionary of National Biography (Oxford University Press, online edn.) [accessed 15 May 2017]. 
Visram, Rozina, Asians in Britain: 400 Years of History (London, Pluto Press, 2002).

Visram, Rozina, Ayahs, Lascars and Princes: The Story of Indians in Britain 1700-1947 (London, Pluto Press, 1986).

West Savali, Kirsten, 'Sister Suffragette: "Slave" T-Shirts Highlight White Feminism's Race Problem', The Root 7 October 2015 http://www.theroot.com/sister-suffragette-slave-t-shirtshighlight-white-fe-1790861323 [accessed 19 May 2017].

Winslow, Barbara, Sylvia Pankhurst: Sexual Politics and Political Activism (London, UCL Press, 1996).

\section{NOTES}

1. IMDB.com/title/tt3077214 [accessed 15 May 2017].

2. For the involvement of working-class women in the suffrage movement, see Jill Liddington and Jill Norris, One Hand Tied Behind Us: The Rise of the Women's Suffrage Movement (London, Virago, 1984); Angela V. John, "Radical Reflections? Elizabeth Robins: The Making of Suffragette History and the Representation of Working-Class Women", in Owen Ashton, Robert Fyson, and Stephen Roberts (eds.), The Duty of Discontent: Essays for Dorothy Thompson (London, Mansell Publishing Ltd, 1995a), pp. 191-211; June Purvis, "The Prison Experiences of the Suffragettes in Edwardian Britain", Women's History Review, 4/1 (1995), pp. 103-33; Sandra Stanley Holton, "Silk Dresses and Lavender Kid Gloves: The Wayward Career of Jessie Craigen, Working Suffragist”, Women's History Review, 5/1 (1996), pp. 129-50; Michelle Myall, “'No Surrender!': The Militancy of Mary Leigh, a Working-Class Suffragette", in Maroula Joannou and June Purvis (eds.), The Women's Suffrage Movement: New Feminist Perspectives (Manchester, Manchester University Press, 1998); Krista Cowman, “'Incipient Toryism' the Women's Social and Political Union and the Independent Labour Party, 1903-1914”, History Workshop Journal, /53 (Spring 2002), pp. 128-48; Krista Cowman, Women of the Right Spirit: Paid Organisers of the Women's Social and Political Union, 1904-1918 (Manchester, Manchester University Press, 2007).

3. See, for example, Sarah Jackson, 'The Suffragettes Weren't Just White Middle-Class Women Throwing Stones' Guardian 12 October 2015 https://www.theguardian.com/commentisfree/2015/ oct/12/suffragettes-white-middle-class-women-pankhursts [accessed 26 July 2017]. Interestingly, it was the class, rather than the race, politics of the film that provoked most debate between historians, Laura Schwartz, "Film Review: Suffragette Explores the Lives of Working-Class Women" History Today 8 October 2015 http://www.historytoday.com/laura-schwartz/filmreview-suffragette, "Suffragette Busts Some Myths But Has Major Holes in Its History" The Conversation 9 October 2015 https://theconversation.com/suffragette-busts-some-myths-but-hasmajor-holes-in-its-history-47325 [accessed 26 July 2017]; Helen McCarthy, 'Suffragette' 15 October 2015 Past Notes http://pastnotes.blogspot.co.uk/[accessed 26 July 2017]; Lucy Delap and Julie Gottlieb, "Suffragette: the Forrest Gump of Feminism" History Matters 3 November 2015 http://www.historymatters.group.shef.ac.uk/suffragette-forrest-gump-feminism/[accessed 26 July 2017]; Diane Atkinson \& Krista Cowman, "Suffragette: 100 Years on Women's Rights Still Prompt Shrill Hysteria", The Telegraph 30 October 2015 http://www.telegraph.co.uk/women/ womens-politics/11965153/Suffragette-100-years-on-womens-rights-still-prompt-shrillhysteria.html [accessed 26 July 2017]; June Purvis “Suffragette: A Reply to Its Critics" 11 November 2015 http://www.historymatters.group.shef.ac.uk/suffragette-reply-critics/ [accessed 26 July 2017].

4. Kirsten West Savali, "Sister Suffragette: 'Slave' T-Shirts Highlight White Feminism's Race Problem", The Root 7 October 2015 http://www.theroot.com/sister-suffragette-slave-t-shirtshighlight-white-fe-1790861323 [accessed 19 May 2017]; Sarah Kwei, "Why I Protested with Sisters 
Uncut at the Suffragette Premier", Independent 8 October 2015 http://www.independent.co.uk/ voices/why-i-protested-with-sisters-uncut-at-the-premiere-of-suffragette-a6685686.html [accessed 19 May 2017]

5. For social media, see Radhika Sanghani, 'The Uncomfortable Truth about Racism and the Suffragettes' http://www.telegraph.co.uk/women/womens-life/11914757/Racism-and-thesuffragettes-the-uncomfortable-truth.html [accessed 19 May 2017].

6. Sarah Gavron, “The Making of the Feature Film Suffragette", Women's History Review 24:6 (2015), 985-995.

7. http://www.timeout.com/london/film/statement-response-t-shirt-complaints [accessed June 2016].

8. Sarah Gavron interviewed by Francine Stock for BBC Radio 4's The Film Programme, broadcast 11 February 2016 [accessed 15 May 2017 BBC radio player].

9. Sumita Mukherjee, “That Indian Suffragettes Photo”, http://sumitamukherjee.wordpress.com/ 2017/02/20/that-indian-suffragettes-photo/[accessed 15 May 2017]. For Sophia Duleep Singh, see Rozina Visram, ' Duleep Singh, Princess Sophia Alexandra (1876-1948)', Oxford Dictionary of National Biography (Oxford University Press, online edn.) [accessed 15 May 2017]; Rozina Visram, Asians in Britain: 400 Years of History (London, Pluto Press, 2002); Anita Anand, Sophia: Princess, Suffragette, Revolutionary (London, Bloomsbury, 2015); Sumita Mukherjee, Indian Suffragettes: Networks, Trans-Nationalism and International Feminism (forthcoming).

10. For Emmeline and Christabel Pankhurst's patriotism see, for example, Nicoletta Gullace, "Christabel Pankhurst and the Smethwick Election: Right Wing Feminism, the Great War and the Ideology of Consumption", Women's History Review 23:3 (2014), pp. 313-346. There is a large historiography on "imperial feminism", for seminal work see Antoinette Burton, Burdens of History. British Feminists, Indian Women, and Imperial Culture, 1865-1915 (Chapel Hill, North Carolina University Press, 1994); Claire Midgley, Feminism and Empire. Women Activists in Imperial Britain, 1790-1865 (London \& New York, Routledge, 2007).

11. Laura Schwartz, 'Knowing Our History Helps Us to Make Better Use of It in the Present', Feminist Fightback, 13 October 2015 http://www.feministfightback.org.uk/some-thoughts-onkirsten-west-savalis-article-sister-suffragette/.

12. For the history of people of colour in Britain prior to large-scale migration following the Second World War, see, for example, Rozina Visram, Ayahs, Lascars and Princes: The Story of Indians in Britain 1700-1947 (London, Pluto Press, 1986); Visram, Asians in Britain; Ron Ramdin, The Making of the Black Working-Class in Britain (Aldershot, Gower Publishing Co., 1987); Rehana Ahmed \& Sumita Mukherjee (eds.), South Asian Resistances in Britain 1858-1947 (London, Continuum, 2012); Caroline Bressey, "Looking for Work: The Black Presence in Britain 1860-1920", Immigrants and Minorities 2 \& 3 (2010), pp. 164-182; Caroline Bressey "Racism, Anti-Racism and the Place of Blackness in the Making and Remaking of the English Working Class", Historical Reflections 41:1 (2015), pp. 70-82.

13. Jewish people from Eastern Europe constituted another racialised yet "white" migrant population from the late nineteenth century onwards.

14. Antoinette Burton, Burdens of History; Claire Midgley, Feminism and Empire.

15. For Law and Besant, see Laura Schwartz, Infidel Feminism: Secularism, Religion and Women's Emancipation, England 1830-1914 (Manchester, Manchester University Press, 2013); for Impey, see Caroline Bressey, Empire, Race and the Politics of Anti-Caste (London: Bloomsbury, 2013).

16. Patricia W. Romero, E. Sylvia Pankhurst: Portrait of a Radical (New Haven \& London, Yale University Press, 1987); Barbara Winslow, Sylvia Pankhurst: Sexual Politics and Political Activism (London, UCL Press, 1996); Mary Davis, Sylvia Pankhurst: A Life in Radical Politics (London, Pluto Press, 1999); Katherine Connelly, Sylvia Pankhurst: Suffragette, Socialist and Scourge of Empire (London, Verso, 2013). 


\section{ABSTRACTS}

This review article examines the debates and controversy surrounding the 2015 film Suffragette. It considers how historians might best engage with the politicisation of their research, and the role of the activist radical historian.

Cet article étudie les débats et controverses autour du film Suffragette, sorti en 2015. Il s'interroge sur le place de l'historien.ne dans le débat public: comment réagir lorsque son objet de recherche se retrouve au cœur du débat public? L'historien.ne engagée a-t-elle un rôle particulier à jouer?

\section{INDEX}

Mots-clés: le film Suffragette, féminisme, féminisme impérial, histoire britannique, histoire publique, histoire radicale

Keywords: Suffragette film, feminism, imperial feminism, British history, public history, radical history

\section{AUTHOR}

\section{LAURA SCHWARTZ}

History Department, University of Warwick 